\title{
The Impact of Political Relation on Economic Development between Libya and China
}

\author{
Mohamed Almnfi and Li-Hua YANG \\ School of Public Administration, Beihang University, 100191, Beijing, China. \\ *Email: almnfi@buaa.edu.cn
}

Keywords: Libya and China, Poetical economic relations; The impact of impact mechanism; Strategies.

\begin{abstract}
The research is an analysis of the past political relation between China and Libya. Further, the study explores how the political relation impacts economic advancement amid both nations. In specific is political relation during the 2011 unrest in Libya. Using already conducted research on China and Libya relations, the study aims at depicting policies China needs to implement, to improve its relation with Libya. As a result, ensure continuous economic growth between both nations.
\end{abstract}

\section{Introduction}

The political relation between two countries has an impact on their economic development. Where the political relations are positive, it is highly likely that the countries cooperate to develop the economies of each other and vice versa as is demonstrated by China and Libya. China has always supported economic developments in Libya. However, owing to political unrests in Libya, China has been reluctant to continue investing in the country. Although China demonstrates interest in investing in Libya, investors risk enormous economic losses in the event of unrest in Libya. The challenges associated with political unrests are unavoidable. These involve the requirement to guarantee the protection of expatriate employees as well as a reliable banking and monetary structure. In specific, the 2011 political unrests in Libya negatively affected economic progress between the two countries.

\section{Problem Statement}

Libya has been marred by continuous political unrests. There have been interstate wars in the country, which have negatively affected the economic growth of the nation [1]. This is especially after the overthrowing of Gaddafi's rule. Despite having a rich resource of oil and gas, the country progresses to be poor. Most of its population is illiterate, lack basic needs, and cannot afford decent housing while unemployment progresses to be high. Apart from the internal challenges arising from Libya's civil wars, there are external challenges. The country lacks a well-functioning government, which poses a risk to investors. China is a country that has demonstrated interest in investing in China. It seeks to benefit from the vast array of natural resources in the country. However, its investment faces numerous predicaments. The political relations amid China and Libya have not been perfect, owing to China's non-intervention policy. Civil unrests in Libya resonate to immense economic losses for Chinese companies that have invested in the different sectors. Thus, resulting in the question: What is the impact of political relation on economic development between Libya and China? By discussing this question, it results in analysis of what foreign policy changes China needs to implement in Libya to salvage their relations.

\section{Literature Review}

The presence of China in African economies, such as Libya, is developing as a significant trade partner and investor in the continent [2]. The presence is notable in sectors such as energy, infrastructure growth as well as retail development all over Africa [3]. What is yet to receive recognition is the expanding position of China's organizations within the manufacturing sectors. 
Venturing in the African market has become possible for China due to the attractive financial agreements and smart international relations [4]. The outcome has been a tenfold development in trade relations between China and Africa, a rise "from US\$10 billion in 2000 to US\$127 billion in 2010, making China the continent's largest trading partner". The trade is subjugated by trading resources for finished products, whereas most Chinese investment has concentrated on sponsoring resources extraction.

China has always invested in Libya, specifically in the oil sector, which has been a basis for the shared economic collaboration connecting the two countries [5]. The collaboration has resulted in mutual benefits for Libyans and Chinese people. China's long-term investment in Libya has been supported by tremendous economic sources, technological knowledge and availability of cheap labor, Chinese investors have ventured into Libya. These investors, both from private and government owned corporations, have invested profoundly in significant sectors of the industry. Some of these sectors are construction, telecommunications, real estate, railroad and oil [6]. Mutual contracts were signed by Libya and China to ease their trade relations.

China and Libya have always had an economic relationship from August 1978. However, this relationship has been marred by unstable political relations. Libya is a large territory with a small population. This is because the desert takes over $98 \%$ of the country [7]. The country is among the wealthiest African nations owing to the rich distribution of gas and oil in the desert [8]. Nevertheless, there is an alarming disparity amid resources and performance. The country progresses to be poor. There is widespread unemployment, lack of education and poor housing. More worrying is the fact that the nation imports most of its foods and close to all industry products, which includes needs.

The challenges Libya faces are attributed to widespread political unrests in the previous four decades.

Libya became a sovereign state in 1951. Prior to its sovereignty, the country was ruled by Spain, Italy, Roman and British kingdoms. Following the United Nations General Assembly decision to make the country independent, it formed a government making Fezzan, Cyrenaica and Tripolitania self-governing states [9]. The federal system of governance came to an end in 1963 paving way for monarch rule. In 1969, Muammar Al-Gaddafi led some militia in staging a coup against King Idris I. The coup was successful resulting in the renaming of the "United Kingdom of Libya" to "Libyan Arad Republic". Under Gaddafi's rule, there were tremendous developments in the country. However, the country experienced a revolution in 2011 resulting in Gaddafi's murder [10].

Research demonstrates that political insecurity has an unconstructive impact on economic development [11]. It results in the shortening of policymakers' horizons resulting in temporary macroeconomic rules. It could as well result in more regular changes to policies, in turn breeding volatility [12]. Economic development is connected to political stability. The insecurity linked to a shaky political environment might minimize investment as well as the pace of economic growth. Also, poor economic development could result in the collapsing of administrations [13]. When a country is faced by political unrests, it means that it has unstable policies, and thus does not favor the interests of investors. This is because; foreign investors favor an environment that is stable, as the policies are certain [14]. A country also suffers from having unstable infrastructure as is the case with Libya.

The revolution has had a negative impact on China's relations with Libya. China has a foreign policy of non-intervention [15]. The decision by Beijing to not support rebels that were key players in the overthrowing of Muammar Gaddafi all through the revolution negatively impacts China's prospect trade with Libya [16]. Contrary to Western nations, China depicted unwillingness in backing rebels from Libya when they sought intervention from the international community [17]. Regardless of failing to support the NTC "National Transitional Council" rebels, China engaged Libya's then administration, via the Egypt and Qatar embassies. The relationship amid China and NTC was marred following the rebels taking over Tripoli.

The Canadian Newspaper depicted that Gaddafi officials had organized meetings with China's government controlled companies involved in the manufacture of arms, "such as the China North Industries Corporation, the China National Precision Machinery Import and Export Corporation, and China XinXing Import and Export Corporation". The newspaper depicted that these Chinese 
manufacturers were willing to breach an arms prohibition enforced on Libya by the United Nations by selling weapons to Gaddafi [18]. Although NTC officials condemned the allegations, Ali Tarhuni, then assistant Prime Minister, declared that such accusations could complicate the possibility of Libya supporting prospect Chinese investment in Libya. This resulted in the storming of the Chinese embassy in Tripoli by Libya's civilians.

Even prior to Libya's civil unrest, the relationship between China and Libya was not smooth. In 1980, Tripoli disengaged with China following Beijing's decision to supply Egypt with arms. This is because Egypt and Libya had previously been engaged in a brief border disagreement. In a different incident, the Chinese National Petroleum company consented to buy Libya's assets from a Canadian organization, Verenex amounting to millions. However, Libya impeded the agreement, compelling the Canadian organization to instead trade with Libya's National Oil Company and at the same time offer a discount. Apparently, China has to repair its relationship with Libya in order to continue investing in the country.

\section{Methodology}

The research uses the literature review that has already been conducted to determine the political relation of China and Libya. Further, the literature analysis is also used in demonstrating how the political relation affects economic development. The literature review acts as qualitative data by providing insight on the views of different authors concerning the political relations between China and Libya. Different authors have their different views, and it is important to review the different views in order to determine whether there is agreement on the research topic. The literature review as well acts as a source of filed study. This is because the information provided by the different sources contains information that has already been researched and conclusions have been made. Analyzing the literature makes it possible to come up with results and a conclusion on the research topic.

\section{Results and Discussion}

The literature review demonstrates that China has a keen interest of investing in African nations. In specific, China is a significant player in Libya's market. For instance, "In 2010, China consumed 11 percent of Libya's oil exports". It acts as Tripoli's second biggest supplier following Italy, "accounting for 10.54 percent of Libyan imports in 2009". Additionally, China has noteworthy trade prospects in Libya [19]. These businesses include railroad projects as well as selling automobiles. Most of China's exports are focused on the telecommunications and construction industries. Prior to the 2011 civil unrest in Libya, Beijing had trade agreements with the country totaling to twenty billion dollars. This can only mean that Libya acts as a profitable market for China.

China looks forward to continued investment in Libya especially now that the country appears to be stabilizing from years of civil unrest. An end to the unrest has resulted in recovery efforts implemented by new governance from the National Transitional Council. NTC approximates that Libya will require to invest close to a hundred billion dollars into home infrastructure projects. It sums up to more than five times the overall value of already established investment by China in Libya. Demand for investment is not just in oil and gas sectors, but other developing sectors like tourism, wind as well as solar energy. Investors from China are at a better position to invest in Libya because they have the technological knowledge as well as monetary resources required in meeting the demand in new and conventional sectors.

Notably, during the 2012 "International Infrastructure Investment and Construction Forum of the China International Contractors Association", it was apparent that China was shifting away from conventional EPC agreements. As a result, Chinese investors have the capability to invest in more profitable PPP or BOT projects, which Libya might be required to provide with the objective of enhancing financial requirements management. China has a proven track record of investing in Libya. It already has ongoing projects in different sectors, most of which were signed during Gaddafi's rule. 
Although China views the prospect stability in Libya as an opportunity to advance investment in the country, it is faced by numerous challenges. The NTC declared its commitment to honor all trade agreements made during Gaddafi's leadership. Realistically, every agreement will require to be re-negotiated under the advent administration owing to changed trading circumstances. Nevertheless, Libya's new government has declared its initiative to offer special treatment in prospect to countries that supported them during the revolution. Bearing in mind that China had a non-intervention policy during the revolution, they stand to lose if Libya decides to adhere to its special treatment policy [20].Without a doubt, China's political relations with Libya, pose a challenge to China's prospect investment in the country.

A different challenge derives from the changes to the legal system by NTC. The new government has declared Sharia rule as the foundation for its legal structure. In addition, the government has promised to make the judiciary self-governing, which will result in respect for international laws. Although these are important changes, it cannot be ascertained that NTC will adhere to the new practices. The outcome of these new laws is that Chinese investors' agreements with the administration will have excluded provisions. The provisions are crucial because they provide performance guarantees like advance payment and security deposit. Supposing that a contract disagreement ensues, investors from China might face hardship in pushing for claim against Libya. Notably, in such a case Libya's judiciary may feel compelled to vote in support of its country.

\section{Conclusion}

It is clear that China has a tainted reputation in Libya owing to its non-intervention policy. This means that China lacks a guarantee for future investment in China, in addition to having to deal with the challenges discussed. China must work towards improving its relation with Libya. China must revise its non-intervention policy to demonstrate to Libya that in the event of prospect unrest, it will intervene and help NTC. Libya faces a challenging task of reconstruction that will require international assistance. Bearing in mind that China has the needed resources and knowhow; it has the advantage of successfully investing in Libya. China must demonstrate its endeavors in Libya towards economic advancement. This will enhance trust amid both nations, improve their political relation and in turn ensure economic advancement amid Libya and China.

\section{References}

[1] Freedom House. Libya, 1-12. Retrieved from: https://www.freedomhouse.org/ sites/default/files/Libya\%202012.pdf

[2] G. Jinyuan, China and Africa: the development of relations over many centuries. African Affairs, (1984) 241-250.

[3] J. Liste, J. Kolster, N. M. Fundani, Chinese investments and employment creation in Algeria and Egypt. African Development Bank, (2012) 1-22.

[4] S.Naidu, D. Mbazima, China-African relations: A new impulse in a changing continental landscape. Futures, 40 (8), (2008). 748-761.

[5] Reuters. China urges Libya to protect oil investments. The Telegraph. Retrieved from: http://www.telegraph.co.uk/finance/china-business/8717571/China-urges-Libya-to-protect-oil-inves tments.html. (2011)

[6] M .Kan, B. Yan, China's investment in Libya. The African Business Journal, 1-1. (2015)

[7] B. Khader, Libya: History of a failed revolution 1969-2011. Retrieved from: http://www.medea.be/2011/05/libya-history-of-a-failed-revolution-1969-\%E2\%80\%93- 2011/

[8] J. Wright, A history of Libya. London: Hurst. (2012) 
[9] D. J. Vandewalle, A history of modern Libya. Cambridge: Cambridge University Press. (2011)

[10] A. A. Ahmida, The making of modern Libya: State formation, colonization, and resistance. Albany: SUNY Press. (2009)

[11] E. Ianchovichina, S. Devarajan, World Bank. Middle East and North Africa economic developments and prospects, October 2013: Investing in turbulent times. Washington: (2013)

[12] A .Aisen, F. J. Veiga, How does political instability affect economic growth? IMF Working Paper, (2010) 3-27

[13] A. Alesina, S. Ozler, N. Roubini, P. Swagel, Political instability and economic growth. Journal of Economic Growth, 1, 2 (1996): 189-211.

[14] Bernal-Verdugo, E. Lorenzo, D. Furceri, D. Guillaume, The Dynamic effect of social and political instability on output: The role of reforms. Washington, D.C: International Monetary Fund. (2013).

[15] M. Liu, China's Libya connection. The Daily Beast. Retrieved from: http://www.thedailybeast.com/articles/2011/06/21/china-s-libya-connection.html (2011)

[16] S. Sotloff, China's Libya problem. The Diplomat. Retrieved from: http://thediplomat.com/2012/03/chinas-libya-problem/

[17] R. Mason, The international politics of the Arab Spring: Popular unrest and foreign policy. New York: Palgrave Macmillan. (2014)

[18] J. Wouters, J. C. Defraigne, M. Burnay, China, the European Union and the developing world: A triangular relationship. Cheltenham: Edward Elgar. (2015)

[19] M. Xinyu, China-Libya ties still vital. China Daily. Retrieved from: http://www.chinadaily.com.cn/opinion/2011-11/02/content_14020093.htm

[20] N. Horesh, E.Kavalski, Asian thought on China's changing international relations. New York: Palgrave Macmillan. (2014) 